\title{
Development of Video Compact Disc as Learning Media to Improve Exposition Writing Ability
}

\author{
Moh. Amin ${ }^{1}$, Andayani $^{2}$, Joko Nurkamto ${ }^{3}, \mathrm{Ngadiso}^{4}$, \\ \{ aminabubakar7@gmail.com $\left.{ }^{1}\right\}$ \\ Universitas Sebelas Maret Surakarta, Indonesia 1,2,3,4
}

\begin{abstract}
Exposition writing is needed by high school students. In addition to the learning process, exposition writing is also useful for students' careers in the future. If after graduating from high school, students choose a career as a trader or entrepreneur, their career will be better known if they have the skills to expose the business in writing. This study aims to describe and explain the development of Video Compact Disc (VCD) as media for learning exposition. This research was carried out at 4 high school in Wonogiri, Indonesia. Data collection techniques using interview technique, observation, questionnaire, and documentation. The results of this study indicate that: 1) VCD is needed in the exposition text learning media by students and teachers which contain several exposition texts at once. 2) There are two parts in VCD exposition text learning, namely in terms of shape and content.
\end{abstract}

Keywords: research \& development, exposition text, VCD (Video Compact Disc).

\section{Introduction}

Writing is a boring thing according to the most people, including senior high school students, it is based on a monotonous teaching and learning process. Teachers use the lecture method and do the practice that always use LKS (Students practice book), not infrequently learning activities are only in the form of saturating theories because they only interact with semi-gray white papers with black marks and it does not seem very interesting to read even understand what it means and its contents. This makes the ability or interest in writing low among high school students in Wonogiri Regency.

Writing is actually one of the communication skills that is very necessary, besides speaking, listening and reading. Writing can be interpreted as a skill and an expertise[1], Skills or abilities are acquired and develop or increase during the process. Writing is an activity in order to express ideas, ideas, and feelings (sad, happy, emotion, happiness, etc.) someone who is expressed in written language[2].

Writing activity is a manifestation of the ability and language skills most recently mastered by a language learner after speaking, reading and listening[3]. Compared to the other three abilities or skills, writing is the most difficult skill to be mastery. Because in writing, a writer must be able to mix words into sentences, sentences into paragraphs, until producing coherent at the end, and from those writings created readings that are ready to be enjoyed by the audience (the readers). 
Some of the writing goals as follows: (1) to tell something in the form of thoughts, ideas, feelings, intuition to be understood by the reader; (2) to provide instructions or direction; (3) to improve reader knowledge; (4) to convince others of their opinions or views about something; (5) to summarize [4]. There are several objectives of learning writing skills based on their level, namely: (1) Beginner Level: copying simple language units, writing simple language units, writing simple statements and questions, short paragraph writing, (2) Intermediate level: writing statements and questions, writing paragraphs, writing letters, writing short essays, writing reports, and (3) Advanced: writing paragraphs, writing letters, writing various types of writing, and writing reports [5].

The goals expected in learning exposition text and development are the students are able to express ideas, opinions and knowledge in writing and also to increase writing interest among high school students in the city of Wonogiri by using VCD (Video Compact Disc) as a learning development media of exposition text. The idea of using VCD is to attract the students interest and enthusiastic in the learning process, because VCD is in a colorful design, and uses pictures and sound also[6]-[8].

Exposition text is an article that aims to provide an argument about the opinion. The term exposition comes from English, "exposition" which means to start or open and reveal. So the purpose of the exposition text is to share, explain or explain the information in detail and answer the question (what, why, when, where, who, how).

From this description, the writer conclude that the exposition text is a writing text that aims to explain in detail about an object by displaying facts that are logical, orderly, integrated and can be believed to be able to expand the reader's knowledge.

\section{Research Method}

This study uses a research and development approach (R \& D) which aims to produce certain products and to test the effectiveness of the products produced. As explained by Sugiyono (2013: 297) research and development (R \& D) is a research method used to produce a particular product, and test the effectiveness of the product[9]. To be able to produce certain products, research is used in the form of needs analysis and to test the effectiveness of these products so that they can used in the wider community, research is needed to test the effectiveness of these products. So research and development are longitudinal (gradually it can be multi years).

The steps in conducting research and development as the learning of exposition writings model with VCD as media according to Borg \& Gall (1983: 775-776) include: (1) Research and data collection (2) Planning (3) Development of product drafts (4) Initial field trial (5) Revising the results of the trial (6) Field trials (7) Improvement of field test products (8) Field implementation tests (9) Final product improvements (10) Dissemination and implementation [10]. This research was conducted in four high schools. The population of the school is Jatisrono 1 Public High School, Wonogiri 3 Public High School, Wonogiri 1 Public High School and 1 Wonogiri Pancasila High School. 120 students became purposive samples in this study. Data collection techniques using technique, observation, questionnaire, and documentation interviews. 


\section{Result and Discussion}

\subsection{Results of media needs analysis VCD learning exposition text}

Student needs description of VCD media profile in learning exposition text. Student needs VCD as exposition text learning media include three aspects, namely (1) whether or not VCD media exposition text learning is needed, (2) VCD text exposition text learning is needed, and (3) student expectations of VCD text exposition text learning. An overview of the indicators of whether or not VCD media exposition text learning is needed can be seen in table 1 below.

Table 1. The need of vcds media for learning exposition texts

\begin{tabular}{clclc}
\hline No & \multicolumn{1}{c}{ Aspects } & Students & \multicolumn{1}{c}{ Answers } & Score \\
\hline 1 Have students ever seen VCDs as exposition text & 30 & Ever & 6 \\
& learning media & & Never & 24 \\
2 & Availability of VCD exposition text as learning & 30 & Many & 0 \\
media circulating in the field & & Little & 30 \\
3 Students' responses to their understanding about & 30 & Clear & 6 \\
VCDs of exposition text as learning media & & Unclear & 24 \\
& & Others & 0 \\
4 The Effectiveness of exposition text VCDs as & 30 & effectively & 4 \\
learning media circulating in the field & & Uneffectively & 0 \\
& & Others & 26 \\
5 The need for other teaching materials in exposition & 30 & Need & 24 \\
text learning & & No need & 6 \\
\hline
\end{tabular}

Based on the data above, it can be concluded that VCD exposition text learning is needed by students to facilitate students understanding in learning exposition text. Indicators needed in VCD as exposition text learning media include: indicators of form needs and content requirements. An indicator of the need for VCD forms of exposition text learning can be seen in table 2 below.

Table 2. Forms of VCD exposition text learning needed

\begin{tabular}{|c|c|c|c|c|}
\hline No & $\begin{array}{c}\text { Assesment } \\
\text { Aspect }\end{array}$ & Students & Answer & $\begin{array}{c}\text { Intencity } \\
\text { Answer }\end{array}$ \\
\hline \multirow[t]{4}{*}{6} & Title & 30 & Write an Exposition with the Scientific Approach to High School & 11 \\
\hline & & & Exposition text VCD as exposition text learning media & 8 \\
\hline & & & Titles made according to the exposition text contained in it & 7 \\
\hline & & & Others & 4 \\
\hline \multirow[t]{4}{*}{7} & Suitable & 30 & Bright and flashy & 3 \\
\hline & Colours & & Simple and casual & 20 \\
\hline & & & Many colours & 4 \\
\hline & & & Others & 3 \\
\hline \multirow[t]{4}{*}{8} & Picture & 30 & People who read exposition text & 12 \\
\hline & & & Theme illustration of exposition text taken by & 13 \\
\hline & & & Abstract & 1 \\
\hline & & & Others & 4 \\
\hline
\end{tabular}


Based on the analysis, it can be concluded that the title used in the VCD prototype of exposition text learning is Exposition Writing with a Scientific Approach for High School. Besides that, students expect VCDs to be used simply and casually. An overview of the indicators of the needs of VCD content for exposition text learning in high school students can be seen in table 3 below.

Table 3. VCDs content for Exposition text learning needed

\begin{tabular}{|c|c|c|c|c|}
\hline No & Assesment Aspect & Students & Answer & Students \\
\hline \multirow[t]{2}{*}{9} & List of menu and display & 30 & Need & 27 \\
\hline & & & No need & 3 \\
\hline \multirow[t]{2}{*}{10} & Instructions for using VCD & 30 & Need & 22 \\
\hline & & & No need & 8 \\
\hline \multirow[t]{2}{*}{11} & The number of exposition text & 30 & One & 6 \\
\hline & themes that will be understood & & Two or more & 24 \\
\hline \multirow[t]{4}{*}{12} & $\begin{array}{l}\text { Options for the theme of the } \\
\text { exposition text to be understood }\end{array}$ & 30 & $\begin{array}{l}\text { Exposition text definition, process, } \\
\text { classification, illustration, } \\
\text { comparisson and analysis }\end{array}$ & 20 \\
\hline & & & $\begin{array}{l}\text { Exposition text classification, } \\
\text { comparisson and analysis }\end{array}$ & 6 \\
\hline & & & $\begin{array}{l}\text { Exposition text classification and } \\
\text { Illustration }\end{array}$ & 3 \\
\hline & & & Others & 1 \\
\hline \multirow[t]{2}{*}{13} & Voice actors & 30 & One & 8 \\
\hline & & & Two or more & 22 \\
\hline \multirow[t]{2}{*}{14} & Whether or not accompanient & 30 & Need & 29 \\
\hline & music (backsound) is needed & & No need & 1 \\
\hline
\end{tabular}

Based on the analysis of these aspects, it can be concluded that the prototype is equipped with manuals users, the display menu list, consisting of 2 or more of expositions text, the exposition text that is used as a VCD is Definition, Process, Classification, Illustration, Comparisson and Analysis, some voice actors and musical instruments. In addition students also expect VCDs to be designed as attractive as possible and can reach other schools.

\subsubsection{Description of Teacher Needs on VCD Media Profile Exposition text learning}

Teacher's need for VCD as media for drama performances includes three aspects, namely (1) whether or not VCD media needs to be exposed to exposition text, (2) VCD media in learning exposition text is needed, and (3) teacher's expectations of VCD media for exposition text learning process. The description of whether or not VCD exposition text learning can be seen in table 4 . below. 
Table 4. Need or not for exposition text VCD as learning media

\begin{tabular}{|c|c|c|c|c|}
\hline No & Aspect & Teachers & Answer & $\begin{array}{l}\text { Intencity } \\
\text { Answer }\end{array}$ \\
\hline \multirow[t]{3}{*}{1} & \multirow{3}{*}{$\begin{array}{l}\text { Have the teachers ever used VCD of } \\
\text { exposition text as the teaching material } \\
\text { in learning process to understand the } \\
\text { exposition text }\end{array}$} & \multirow[t]{3}{*}{3} & Ever & 0 \\
\hline & & & Never & 3 \\
\hline & & & Others & 0 \\
\hline \multirow[t]{3}{*}{2} & \multirow{3}{*}{$\begin{array}{l}\text { Media used by the teacher in learning } \\
\text { exposition text }\end{array}$} & \multirow[t]{3}{*}{3} & Power point & 0 \\
\hline & & & $\begin{array}{l}\text { Exposition text learning } \\
\text { media }\end{array}$ & 0 \\
\hline & & & Others & 3 \\
\hline \multirow[t]{5}{*}{3} & \multirow{5}{*}{$\begin{array}{l}\text { Factors that become the obstacles in } \\
\text { learning to understand the exposition } \\
\text { text }\end{array}$} & \multirow[t]{5}{*}{3} & Students & 3 \\
\hline & & & $\begin{array}{l}\text { Lack of teaching } \\
\text { material }\end{array}$ & 0 \\
\hline & & & Lack of teaching & 0 \\
\hline & & & knowledge & \\
\hline & & & Others & 0 \\
\hline \multirow[t]{3}{*}{4} & \multirow{3}{*}{$\begin{array}{l}\text { Student responses in learning process to } \\
\text { understand the exposition text }\end{array}$} & \multirow[t]{3}{*}{3} & Good & 2 \\
\hline & & & Not Good & 0 \\
\hline & & & Others & 1 \\
\hline \multirow[t]{3}{*}{5} & \multirow{3}{*}{$\begin{array}{l}\text { Availability of VCDs for exposition text } \\
\text { learning media in the field }\end{array}$} & \multirow[t]{3}{*}{3} & So many & 0 \\
\hline & & & Little & 1 \\
\hline & & & Others & 2 \\
\hline \multirow[t]{3}{*}{6} & \multirow{3}{*}{$\begin{array}{l}\text { Quality of VCD exposition text learning } \\
\text { in circulation }\end{array}$} & \multirow[t]{3}{*}{3} & Good & 0 \\
\hline & & & Poor in quality & 1 \\
\hline & & & Others & 2 \\
\hline \multirow[t]{2}{*}{7} & \multirow{2}{*}{$\begin{array}{l}\text { Whether or not learning media is needed } \\
\text { in learningexposition text }\end{array}$} & \multirow[t]{2}{*}{3} & Need & 3 \\
\hline & & & No need & 0 \\
\hline \multirow[t]{3}{*}{8} & \multirow{3}{*}{$\begin{array}{l}\text { Teaching materials that need to be } \\
\text { developed in current exposition text } \\
\text { learning. }\end{array}$} & \multirow[t]{3}{*}{3} & $\begin{array}{l}\text { VCD as exposition text } \\
\text { learning media }\end{array}$ & 3 \\
\hline & & & $\begin{array}{l}\text { Exposition text learning } \\
\text { book }\end{array}$ & 0 \\
\hline & & & Others & 0 \\
\hline \multirow[t]{2}{*}{9} & \multirow{2}{*}{$\begin{array}{l}\text { Whether or not VCD music illustrations } \\
\text { are needed in Exposition text learning } \\
\text { media }\end{array}$} & \multirow[t]{2}{*}{3} & Need & 3 \\
\hline & & & No need & 0 \\
\hline \multirow[t]{2}{*}{10} & \multirow{2}{*}{$\begin{array}{l}\text { The number of exposition text themes } \\
\text { that should be in the exposition text } \\
\text { learning }\end{array}$} & \multirow[t]{2}{*}{3} & One only & 0 \\
\hline & & & Two or more & 3 \\
\hline 11 & Number of voice actors & 3 & 1 person & 1 \\
\hline & & & 2 people or more & 2 \\
\hline 12 & The need for other teaching materials of & 3 & Need & 3 \\
\hline & exposition text learning media & & No need & 0 \\
\hline
\end{tabular}

Based on the analysis of several aspects, it can be concluded that exposition learning VCDs are rarely found, even if VCDs are found, they have poor display picture and content, so they need a redesign then the VCD contains interesting images and contents that are easy to understand.

In the aspect of VCD, exposition text learning needed some parts of form and content. The form section includes three indicators, namely 1) title, 2) cover color, and 3) cover picture. The following is a description of the three aspects of the assessment. 
Table 5. Forms of VCDs for learning exposition text

\begin{tabular}{|c|c|c|c|c|}
\hline No & Aspect & Teachers & Answer & $\begin{array}{r}\text { Intencity } \\
\text { Answer }\end{array}$ \\
\hline \multirow[t]{5}{*}{13} & \multirow{5}{*}{$\begin{array}{l}\text { Title of exposition text learning } \\
\text { VCD }\end{array}$} & \multirow[t]{5}{*}{3} & Exposition Writing with Scientific & 2 \\
\hline & & & Approach for Senior High School & \\
\hline & & & $\begin{array}{l}\text { VCD of learning Exposition text as } \\
\text { exposition learning media }\end{array}$ & 0 \\
\hline & & & $\begin{array}{l}\text { Judul yang dibuat sesuai dengan } \\
\text { tema teks eksposisi yang ada } \\
\text { didalam VCD }\end{array}$ & 1 \\
\hline & & & Lainnya & 0 \\
\hline \multirow[t]{4}{*}{14} & Colors made & \multirow[t]{4}{*}{3} & Bright and striking & 1 \\
\hline & consideration in designing & & Simple and casual & 0 \\
\hline & cover of exposition text & & So many colours & 0 \\
\hline & learning VCD & & Others & 2 \\
\hline \multirow[t]{4}{*}{15} & $\begin{array}{l}\text { Images that used as cover for } \\
\text { exposition text learning VCD }\end{array}$ & \multirow[t]{4}{*}{3} & $\begin{array}{l}\text { People who read } \\
\text { Exposition text }\end{array}$ & 2 \\
\hline & & & Exposition text illustration taken by & 1 \\
\hline & & & Abstract & 0 \\
\hline & & & Others & 0 \\
\hline
\end{tabular}

Based on the analysis of these aspects, it can be concluded that the title used in the VCD of exposition text learning is the Exposition Writing with the Scientific Approach for Senior High School students with a casual and simple color design and is equipped with an illustration of the exposition text theme taken. Meanwhile, the content section includes three aspects of assessment. Here's the full explanation.

Table 6. The Contents of exposition text VCDs

\begin{tabular}{clclc}
\hline No & \multicolumn{1}{c}{ Aspect } & Teachers & \multicolumn{1}{c}{ Answer } & $\begin{array}{c}\text { Intensity of } \\
\text { Answer }\end{array}$ \\
\hline 16 & $\begin{array}{l}\text { Whether or not music needs in VCD of } \\
\text { exposition text as learning media }\end{array}$ & 3 & Need & 3 \\
17 & $\begin{array}{l}\text { Amount of exposition texts that should } \\
\text { be included in exposition text VCD as }\end{array}$ & 3 & One only & 0 \\
& learning media & & Two or more & 1 \\
18 & Amount of actors voice & 3 & 1 person & 2 \\
& & & Two people or more & 1 \\
\hline
\end{tabular}

Teacher's expectation of exposition text VCD as learning media, those are: (1) Capable to improve students' learning interest in understanding exposition text, (2) Capable to improve students understanding of exposition texts, (3) Capable to inspire and motivate teachers and students to maximize Indonesian language learning, especially writing skills of exposition text, (4) The VCDs of exposition text learning made creatively and innovatively to facilitate exposition text learning through scientific approaches. 
The Principles for Developing VCDs as Exposition Text Learning Media for Xth Grade Students. Principles of VCD Development of Exposition Text as Learning Media. The principles in developing VCD as an exposition text learning media include:

Principles of Interesting and Exciting

Principle of Easely

Principle of Flexibility

Principles of Innovative

Principle of Relevance

Principle of Creativity

The principle of using VCD as an exposition text learning media, such as:

Principle of Easely

Principles of Innovative and Creative

Prototype of Exposition Text VCD. The materials used in making exposition text VCD as learning media. The material used in making VCDs of exposition text as learning media in the form of exposition texts are filmed. The exposition texts that will be used in making this media are exposition texts entitled definition and exposition of process.

The production process of exposition text as learning media. In the production process stage, researchers describe activities carried out during the production process, those are: (1) the formation of a production team, (2) the process of developing exposition texts into scripts, and (3) shooting.

Postproduction (process of editing VCD exposition text learning). The VCD editing process uses the SPARKOL VIDEO SCRIBE program, ADOBE AFTER EFFECT CS 4, COREL X5, and PHOTOSHOP CS4. This process consists of four stages, such as: (1) inserting video, (2) inserting audio, (3) adding text, (4) generating a VCD.

Assessment and Suggestion for Improvement of VCD Prototype of exposition text as learning media. Based on limited trials conducted on 3 teachers and 2 experts, the results of the study are as follows. The assessment includes three dimensions, namely 1) VCD display, 2) text menu, and 3) main / content menu.

In the first dimension of exposition text $\mathrm{VCD}$ as learning media, the average score obtained from the teacher is 3 and from the expert is 3. Based on the both of score, the average value is 3 , so it can be concluded that the dimensions of VCD are good. In addition assessment above, there are some improvement suggestions for this dimension, namely the VCD background color should be brighter and the image highlighted is the exposition text theme not the voice filler. The second dimension is the VCD text menu, the average score obtained from the teacher is 3 and from the expert as well 3. Based on these scores obtained on average by 3 , it can be concluded that the text menu dimensions on the VCD are good.

Beside to the assessment above, there are some suggestions for improvement in this dimension, namely (1) the font size on the cover should enlarged, (2) the color of the letters are given bright colors, and (3) the text of the lyrics at a glance on the video is made full or all included with given various effects.

The third dimension is the contents of the $\mathrm{VCD}$, the average score obtained from the teacher is 3 and from the expert 3. Based on both of values obtained on average is 3 , it can be concluded that the main menu dimensions of VCD are good. In general, there are some improvement suggestions given by the teacher and experts on the instructional materials for 
reading book exposition texts, namely (1) the color of the VCD's background change is clarified and made with a more attractive design, (2) the music illustration is replaced with a soft and sound reduced, (3) the font size and color are enlarged and given an interesting effect with bright colors, and (4) on the back of the VCD is given a text about VCD. Based on the assessment carried out by the supervisor lecturer, overall VCDs are good even though there are some improvements, namely the use of greeting words addressed to teachers or education practitioners. In addition, the things that must be improved are the writing of letters, sentence, and cover that is adjusted to changes in the VCD cover.

After assessing the VCDs of exposition text as learning media for Xth grade of senior high school students by teachers and experts, the assessment results and input suggestions were obtained as the basis for improvement of this exposition text VCD as learning media, all input suggestions obtained were used as a basis for improvement. However, not all input suggestions obtained are used as a basis for improvement because researchers have their own concepts and considerations in revising or improving VCDs of exposition text as learning media. In addition to referring the suggestions for improvement, the improvements made are also based on researchers' creative ideas.

The dimensions of the VCD display. Improvements made at VCD display are (1) the color changes on the cover become brighter, (2) changes the font size and color of the title, and (3) changes to the cover image that are highlighted by the exposition text theme. Improvements to the VCD label and wrap of exposition text.

On the VCD cover, it is designed only slightly differently on the color of the VCD image. The color before revise looks less bright and striking, and the revise are given in blue and rather striking. In addition, the theme of the contents of the exposition text is more highlighted in the form of an umbrella festival picture. Changes to VCD text font, the text font is changed from black to yellow. The color was chosen by the researcher because it was bright and easy to read.

\section{Test the Results of Development of Learning VCD Models}

Limited Test. The results of VCD development based on Limited Trials in Senior High School.

Limited Trial 1.Trial activities limited 1 in development of video compact disc (VCD) through scientific approach of exposition writing as learning media in senior high schools (SMA) held on Wednesday, November 2, 2016, for 90 minutes (1 meeting), 08.30 to 10.00 WIB . Limited trial 1 was carried out in the Language Laboratory room, SMA Negeri 1 Jatisrono, Wonogiri. The implementation of the limited trial 1 was assisted by the Indonesian Language teacher, Yani Purwanti, SPd at the first semester of the 2016/2017 academic year of class X MIPA 1 that consists of 30 students.

Limited Trial 2. Limited trial 2 was carried out by implementing a compact disc video prototype. Writing Exposition about the Types of Exposition. The implementation of this limited trial 2 was still carried out in the Language Laboratory room of SMA N 1 Jatisrono on Wednesday, 9 November 2016, for 90 minutes (1 meeting), 08.30 to 10.00 WIB. The implementation of the limited trial 2 is still assisted by the Indonesian Language teacher, Mrs. Yani Purwanti, SPd in the class X MIPA 1 at the first semester (2016/2017) that consists of 30 students. 
At the end of the limited test 2, the researcher asks permission to the teacher to provide multiple choice test questions, to find out the students progressive learning outcomes after using VCD as an exposition learning media. Based on the limited test results, there are significant differences from the results of the pre-test and post test. It can be stated that the VCD of exposition learning media with a scientific approach is quite effective in improving the learning outcomes of the exposition text of the students of SMA Negeri 1 Jatisrono Wonogiri.

Extensive Test. Extensive testing is the continue of limited testing conducted to ensure the feasibility of VCD media development results have met the needs of learning media needed by students and teachers. Extensive testing was carried out in three schools, those are: SMA N 1 Wonogiri, SMA N 3 Wonogiri and SMA Pancasila 1 Wonogiri. In the broad of test, the achievement of learning outcomes was analyzed before the use of VCD media as a result of the development and achievement of learning outcomes after the use of VCD media from the development results. Based on the results of the test analysis, it can be seen that there are differences in the results of learning Indonesian before and after the use of VCD media as a result of development. The important point is that VCDs as learning media are declared effective in improving student learning achievement.

\section{Discussion}

The advantages of exposition text VCD as learning media for Xth grade senior high school sstudents. When compared with the existing VCD media, the instructional material made by the researcher is superior in terms of form and content. This media is more effective, with a very interesting design, it can facilitate students in understanding exposition text, so that learning outcomes will be better. This VCD is very practical and easy to carry anywhere[11], [12].

Audiovisul Media Deficiency (VCD) VCD exposition text learning media for Class X High School Students. The lack of VCD exposition text learning, that is, the contents of the VCD both the way of reading and the exposition text background presented in the video are still very simple so that the level of satisfaction as teaching material depends on the student and the teacher itself[4], [13], [14].

\section{Conclusion}

Teaching materials to appreciate the exposition text for senior high school students of Xth grade can be developed into VCDs in exposition text learning media. The VCD can be used as the alternative learning media, that contains of 6 exposition texts, those are: exposition text on coffee making, exposition text about trade growth in Solo, exposition text about orderly traffic area, the text of the comparative exposition themed Sangiran Archaeological Museum, the exposition text of the analysis themed the cause of the weakening of the rupiah. The cover of the box and the appearance of VCD media are made more attractive, it can be motivate students in improving their learning process. 
The conclusions relate to the need for VCD exposition text as learning media, those are: (1) Based on an analysis of the needs, it is known that students and teachers need exposition text learning media which is then applied in the form of VCD as learning media. (2) In terms of form, the title used in the VCD prototype exposition text learning is exposition writing with the scientific approach to senior high school students and the selected picture is an exposition text with simple and casual colors. In terms of the contents of the VCD exposition text learning is equipped with a list of display menus, in the form of exposition text with a scientific approach to senior high school students accompanied by audio or sound. (3) Conclusions about the evaluation of the prototype media VCD of the exposition text for the Xth grade senior high school students. From the results of the assessment given by expert lecturers and teachers, it can be concluded as follows: (1) the dimensions of the VCD exposition text learning the average score obtained from the teacher 3 and from the expert 3 , it can be concluded that the dimensions of the VCD are good, (2) in the text menu dimension $\mathrm{VCD}$, the average score obtained from the teacher is 3 and from expert 3 it can be concluded that the text menu dimensions VCD is good, and (3) on the dimensions of VCD content, the average score obtained from the teacher is 3 and from expert 3 , it can be concluded that the main menu dimensions of VCD are good.

Improvements made to the prototype VCD media of exposition text learning media, those are: (1) The dimensions of VCDs packaging for exposition text learning, a total design change was made. However, still using the first concept of displaying the themes of both the video and the two reader models, (2) The dimensions of exposition text VCD as learning media, should matches with the box cover of exposition text VCD, (3) The text of dimensions menu are added and corrected on the composition of color and size.

\section{References}

[1] S. A. Crossley and D. S. McNainara, "Say more and be amore coherent: How text elabration and cohension can incresase writting quality," J. Writ. Res., vol. 7, no. 3, pp. 351-370, 2015.

[2] I. Rosidi, Menulis Siapa Takut. Yogyakarta, INDONESIA: Kanisius., 2009.

[3] L. Abu-Lughod, "Writting against "culture," in Recapturing Anthropology, 1991, pp. 191-210.

[4] A. Semi, Menulis Efektif. PADANG, INDONESIA: Angkasa Raya., 1990.

[5] D. Iskandarwassid dan Sunendar, Strategi Pembelajaran Bahasa. INDONESIA: PT. Remaja Rosdakarya., 2008.

[6] P. De Lancie, “Apple Debuts DVD Strategy,” EMedia Mag., vol. 14, no. 5, p. 38, 2001.

[7] Y. Tsuchiya, S. Kajiyama, Y. Kano, Y. Matsumura, and S. Ichiura, "Digital video disc/compact disc compatible pick-up with liquid crystal shutter," Japanese J. Appl. Physics, Part 1 Regul. Pap. Short Notes Rev. Pap., vol. 36, no. 1 B, pp. 481-485, 1997.

[8] A. Purnama, "Video Compact Disc (VCD) Technology and Film Education in Southeast Asia: The Case of Indonesia," in The Film Archive as a Research Laboratory, 2014.

[9] Sugiyono, Metode Penelitian Kuantitatif, Kualitatif dan R\&D. Bandung, Indonesia: Bandung: Alfabeta., 2013.

[10] W. R. Borg and M. D. Gall, Educational Research: An Introduction. New York: Longman.: Longman, 1983.

[11] J. Taylor, "DVD-Video: M ultimedia for the Masses," IEEE Multimedia, vol. 6, no. 3. pp. 8692, 1999.

[12] W. K. Chow and S. S. Han, "Studies on fire behaviour of video compact disc (VCD) materials with a cone calorimeter," Polym. Test., vol. 23, no. 6, pp. 685-694, 2004.

[13] K. Rukun, A. Huda, Y. Hendriyani, and S. Hartanto, "Designing interactive tutorial compact disc (CD) for computer network subject," J. Teknol., vol. 77, no. 23, pp. 21-26, 2015. 
[14] S. J. Golin et al., “Adaptive digital video compression system,” 1989. 